\title{
The role of innovation in changing early upper paleolithic organic projectile technologies
}

Heidi Knecht

\section{(2) OpenEdition \\ 12 Journals}

Electronic version

URL: https://journals.openedition.org/tc/689

DOI: $10.4000 /$ tc.689

ISSN: 1952-420X

Publisher

Éditions de l'EHESS

Printed version

Date of publication: 1 November 1992

ISSN: 0248-6016

\section{Electronic reference}

Heidi Knecht, "The role of innovation in changing early upper paleolithic organic projectile

technologies", Techniques \& Culture [Online], 17-18| 1992, Online since 10 January 2006, connection on 29 September 2022. URL: http://journals.openedition.org/tc/689 ; DOI: https://doi.org/10.4000/tc.689

This text was automatically generated on 29 September 2022.

All rights reserved 
The role of innovation in changing early upper paleolithic organic projectile technologies

Heidi Knecht 